\title{
Nzema Language
}

National Cancer Institute

\section{Source}

National Cancer Institute. Nzema Language. NCI Thesaurus. Code C154066.

A Central T ano language spoken by the Nzema people of southwestern Ghana and southeast Ivory Coast. 